\title{
BELAJAR DARI PASANG SURUT PERADABAN BOROBUDUR DAN KONSEP PENGEMBANGAN PARIWISATA BOROBUDUR
}

\author{
M. Baiquni \\ Fakultas Geografi dan Pusat Studi Pariwisata \\ Universitas Gadjah Mada \\ baiquni@lead.or.id
}

\begin{abstract}
Borobudur is a famous tourism destination which is listed as a World Heritage Site listed in 1991. Recently the condition of the temple is threatened with many problems related to tourist behaviors, overcrowded vendors and traders, as well as managerial issues. This research was carried out with literature study, field observation, peer discussion and seminar. Reflecting the history, this research tried to explain the rise and fall of civilization. This research tried to explain Borobudur as magnet for tourism destination and tourism as locomotive for community and regional development. There are five reasons why glory of civilization can fall even dramatically: (1) horizontal conflicts among social groups; (2) intrigue and struggle for power among elite leaders; (3) expansion and occupation from foreign power; (4) environmental degradation; and (5) disasters like volcanic eruption, earthquake and tsunami. Borobudur has many enigmas, when and why the fall of its civilization. It is not easy to explain these enigmas. The results of this research are: (1) It is possible combination of causes the fall of Borobudur civilization, but the most possible was volcanic eruptions of Merapi. (2) Borobudur has problems related to the tourist number who disturb the stone relief and statues when they climb up the temple (3) Tourists disappointed to lack of hospitality and low quality of services provided by the management as well as the vendors and traders. (4) The problems of conservation related to environmental changes. Among others, prime recommendation is "Rethinking Borobudur" to get new alternative and strategy to manage this world heritage.
\end{abstract}

Keywords: Enigma Borobudur, rise and fall of civilization, tourism and regional development

\section{PENDAHULUAN}

Borobudur merupakan salah satu warisan dunia yang terkenal dan masuk dalam World Heritage List dengan nomor C592 pada tahun 1991, namun belakangan mengalami kemerosotan pamor di dunia internasional. Sejak saat itu Candi Borobudur dipacu sebagai daya tarik wisata yang dikelola oleh BUMN. Dalam pengelolaan dan pemanfaatan Candi
Borobudur sebagai daya tarik wisata ternyata membawa dampak pada nilai-nilai penting warisan budaya ini maupun dampak sosial, ekonomi, dan budaya masyarakat yang ada di sekitarnya. Tidak jarang dampak ini justru menimbulkan masalah-masalah baru yang rupanya tidak terduga dan kurang teperhatikan sebelumnya. Berbagai perbedaan kepentingan telah berkembang menjadi persaingan dan bahkan konflik antara berbagai pihak yang 
terlibat dalam pengelolaan dan pemanfaatan candi ini.

Masalah penurunan pamor ini diduga akibat tekanan pemanfaatan yang lebih dominan dibanding konservasi situs purbakala ini. Ditambah pula dengan kesiapan aparat daerah dalam pengelolaan kawasan pariwisata terkait dengan otonomi daerah, konflik kepentingan berbagai pihak terhadap keberadaan candi, serta kurang tanggapnya pengelola untuk mengantisipasi dan mengatur perkembangan tersebut. Sejumlah keluhan wisatawan berkaitan dengan pelayanan dan sikap perilaku para pendagang dalam menyodorkan dagangannya mulai muncul. Demikian pula keluhan para pedagang dan warga terhadap pengelola berkaitan dengan berbagai peraturan yang menurut mereka perlu ditinjau kembali. Pengelolaan warisan dunia ini perlu segera dibenahi agar dapat lestari dan bermanfaat bagi masyarakat.

Memikirkan kembali keberadaan Candi Borobudur sebagai pusat peradaban maupun magnet pariwisata diperlukan kajian dari berbagai cara pandang dan analisis kritis. Upaya berbagai pihak untuk memikirkan kembali Borobudur diperlukan sebagai masukan bagi konsep baru yang dapat mengangkat potensi tidak hanya candi sebagai bangunan, tetapi juga lansekap bahkan juga saujana budaya di desa-desa sekitarnya. menampung berbagai kepentingan dan dinamika yang berkembang.

Berdasarkan prasasti Karangtengah dan Kahulunan, pendiri Borobudur adalah Dinasti Syailendra. Bangunan raksasa itu mulai dibangun tahun $770 \mathrm{M}$ dan baru dapat diselesaikan pada 842 M. Beberapa studi berusaha membangun teori untuk menjelaskan Borobudur. Salah satunya menyatakan bahwa nama ini kemungkinan berasal dari kata Sambharabhudhara, yaitu artinya "gunung" (bbudara) di mana di lereng-lerengnya terletak teras-teras. Selain itu terdapat beberapa etimologi rakyat lainnya. Misalkan kata borobudur berasal dari ucapan "para Buddha" yang karena pergeseran bunyi menjadi borobudur. Penjelasan lain ialah bahwa nama ini berasal dari dua kata "bara" dan "beduhur". Kata bara konon berasal dari kata vihara, sementara ada pula penjelasan lain di mana bara berasal dari bahasa Sansekerta yang artinya kompleks candi atau biara dan bedubur artinya ialah "tinggi", atau mengingatkan dalam bahasa Bali yang berarti "di atas". Oleh karena itu dapat dimaknai sebagai sebuah candi yang berada di tanah tinggi (Soekmono, 1976 dan Soeroso, 2007).

Peninggalan budaya yang kini masih memiliki bentuk yang menarik dan unik ini, maka Borobudur layak sebagai warisan dunia UNESCO dan menjadi obyek wisata pendidikan peradaban bagi generasi kini dan menndatang. Perhatian dunia terhadap Borobudur sebagai warisan dunia ini telah menjadi magnet, manarik wisatawan untuk berdatangan melihat dan menikmati Borobudur. Peninggalan sejarah Borobudur memiliki arti penting bagi peradaban kini dan masa depan. Oleh karena itu memang harus dikonservasi dan juga dapat dimanfaatkan secara lestari.

Orientasi pelestarian world heritage's UNESCO telah bergeser perhatiannya. Pada masa lalu pelestarian ditujukan untuk melindungi komponen bangunan fisik, situs material atau artefak peninggalan masa lalu dengan menekankan pada kepentingan politik penguasa; maka pada masa kini orientasinya telah berubah dengan lebih memperhatikan pada manusia sebagai pengemban budaya dan pelestari 
Tabel 1. Pergeseran Paradigma Pengelolaan Pusaka Dunia UNESCO

\begin{tabular}{ll}
\hline \hline \multicolumn{1}{c}{ Paradigma Lama } & \multicolumn{1}{c}{ Paradigma Baru } \\
\hline Monumen raja, pendeta, politik & Tempat dan ruang manusia biasa \\
Kosong, situs material & Masyarakat berkelanjutan \\
Komponen fisik & Tradisi dan praktik kehidupan \\
Manajemen administrasi oleh pusat & Pembangunan masyarakat, desentralisasi \\
Penggunaan elit (untuk rekreasi) & Penggunaan populer (untuk pembangunan)
\end{tabular}

Sumber: Soeroso, 2007

nilai yang diyakininya. Fokus kepentingannya adalah pada pembangunan masyarakat yang berkelanjutan sehingga menekankan perlunya memperhatikan tempat dan ruang manusia yang ada di sekitarnya lengkap dengan tradisi dan praktik kehidupan kesehariannya.

Perubahan paradigma ini terjadi belum lama, sehingga terasa upaya pemugaran dan pembagian zonasi yang dilakukan pada tahun 1970-an terhadap Borobudur jelas hanya berorientasi pada kepentingan perlindungan Candi Borobudur semata. Keterlibatan masyarakat dan pembangunan wilayah disekitarnya masih kurang mendapat perhatian dalam pemugaran Borobudur. Komplek Candi Budha ini dibentuk atau diperlakukan sedemikan rupa sehingga memiliki posisi eksklusif yang berjarak dengan kehidupan masyarakat di sekelilingnya. Padahal lingkungan hidup kawasan di sekitarnya, baik alam, maupun budaya komunitasnya, tidak kalah penting karena sebenarnya kelestarian candi akan tergantung pada peran para pengemban budayanya. Bila hal ini berlangsung terus dikhawatirkan akan mengganggu eksistensi situs dengan menurunkan kualitas baik candi maupun lingkungan di sekeliling kawasan Borobudur, seperti terlihat pada Tabel 1 (Soeroso, 2007).
Pengembangan pariwisata memerlukan tiga hal berkaitan dengan akses, atraksi dan amenitas dikenal dengan Triple A (Access, Attraction and Amenity). Borobudur kaitannya dengan pariwisata menjadi magnet atau daya tarik yang kuat, tidak saja karena letaknya yang berada di tengah Pulau Jawa sehingga mudah diakses dari kota-kota besar, tetapi juga merupakan monument peninggalan nenek moyang yang sarad dengan sejarah dan pelajaran hidup. Akses menuju Borobudur dapat dijangkau dari berbagai penjuru melalui kota Yogyakarta yang memiliki jaringan transportasi kereta api dan airport, juga dari arah utara dapat dijangkau dari Semarang yang memiliki akses darat, udara dan laut.

Atraksi yang ada di Borobudur memang memiliki keunikan yang didukung oleh alam sekitar dan budaya yang diemban mansarakat. Borobudur sudah menjadi obyek sekaligus atraksi yang beragam yang dapat dinikmati dengan waktu berbeda. Kini juga telah dibuka kunjungan pada subuh dinihari untuk menikmati suasana matahari terbit. Belum lagi beragam atraksi yang dapat digali dari masyarakat kampung-kampung sekitar Borobudur, berupa kesenian dan fenomena budaya maupun kehidupan sehari-hari. 
Amenitas atau yang berkaitan dengan fasilitas kenyamanan seperti hotel dan restoran maupun sarana penunjang. Borobudur memiliki beragam kelas hotel, mulai dari kelas super eksklusif seperti Aman Jiwo hingga kelas homestay sederhana yang akrab dengan kehidupan sehari-hari masyarakat setempat. Ketersediaan berbagai fasilitas juga dapat diperoleh di luar kawasan Borobudur, tidak jauh dari sini dalam jangkauan jarak 40 kilometer terdapat banyak amenitas yang tersedia di kota Magelang dan Yogyakarta.

Keberadaan Borobudur ditinjau dari pariwisata memang memiliki keunikan, kekhasan dan otentisitas yang tiada duanya atau sulit ditandingi. Meskipun Borobudur masih banyak diselimuti permasalahan, tetapi masih menyimpan potensi dan tekateki yang menarik untuk disingkap dan diungkap untuk pembelajaran peradaban bagi generasi kini dan mendatang.

Penelitian mengenai Borobudur ini bertujuan untuk:

1. Memahami latar belakang sejarah pasang surut peradaban dari tinjauan historis.

2. Menganalisis potensi daya tarik (magnet) pariwisata warisan dunia Candi Borobudur.

3. Mengembangkan konsepsi dan strategi pengembangan pariwisata Borobudur dikaitkan dengan pengembangan masyarakat dan pembangunan wilayah sekitarnya.

\section{METODE PENELITIAN}

Metode penelitian dilakukan dengan studi literatur, observasi dan penjaringan data maupun informasi melalui diskusi ahli (peer discussion). a. Studi literatur: merupakan upaya untuk menjelajahi berbagai data dan informasi, termasuk beragam pandangan dan analisis dari para ahli yang tertuang dalam buku, jurnal, laporan penelitian maupun informasi dari internet.

b. Observasi: merupakan upaya untuk penggalian data dan informasi di situs Candi Borobudur dan kampung di sekitarnya. Fenomena yang diamati berupa fisik bangunan candi dan lansekap wilayah, dinamika penduduk maupun saujana budaya. Observasi dilakukan dengan cara mengamati, mencatat dan menghubungkan beberapa data maupun informasi lapangan.

c. Diskusi ahli (peer discussion): merupakan upaya membahas berbagai data dan informasi dengan cara pandang yang beragam yang dikemukakan oleh para ahli dengan latar belakang pengetahuan dan pengalaman yang beragam (antara lain Arkeologi, Antropologi, Arsitektur dan Geografi). Diskusi dan perdebatan menjadi cara untuk menguji argumen, mengkarifikasi data dan informasi, serta menemukan pandangan baru dari proses berfikir kritis.

\section{HASIL DAN PEMBAHASAN}

\section{Peradaban Intermountains Basin}

Manusia dalam berhubungan dengan sumber daya alam dipengaruhi oleh kebutuhan intrinsik dan faktor lingkungan yang berpengaruh terhadap kelangsungan hidupnya (Subaktini, 2006). Intermountains basin atau lembah antar pegunungan merupakan salah satu lingkungan hidup yang menarik bagi peradaban manusia. 
Sudah sejak lama tempat semacam ini merupakan pilihan unggul tidak saja dikelilingi pemandangan yang indah, tetapi juga dari segi sumber daya alam memiliki tanah yang subur, air yang melimpah dan sungai-sungai yang bisa menjadi sumber untuk tanaman pangan, air minum untuk ternak dan perikanan.

Lembah antar pegunungan dengan sungai besar menjadi pilihan untuk pusat peradaban mengingat daya dukung kehidupan yang penting seperti ketersediaan air dan tanah yang subur. Sebagaimana dapat kita saksikan sejarah peradaban di tepi Sungai Nil, Sungai Yangtse, lembah subur Sungai Eufrat dan Tigris, lembah di bawah pegunungan 'atap dunia' Himalaya yang dialiri Sungai Gangga. Berbagai peradaban besar yang pernah muncul itu juga mengalami pasang dan surut, bahkan tenggelam ditelan masa. Maka terjadilah pergeseran pusat peradaban dari satu tempat ke tempat lainnya secara silih berganti. Pasang surut dianalisis berbagai ahli dengan beragam sudut pandang mulai dari pandangan yang sifatnya Entropi hingga pandangan adanya Catastrophe (Fagan, 2008).

Borobudur terletak di lembah antar pegunungan, merupakan candi yang dibangun dengan batu beku vulkanik yang hingga kini masih bisa dilihat dan dinikmati. Bangunan Candi Borobudur terletak di tanah tinggi yang dikelilingi danau yang dalam perspektif landscape yang luas tempat ini termasuk intermountains basin. Panorama dari kejauhan puncak pegunungan, tampaklah Borobudur bak bunga teratai yang mekar diatas kolam.

Borobudur tidak berdiri sendiri, pada masa jayanya bermunculan pusat-pusat permukiman dengan candi yang hingga kini masih dapat dilihat dan menjadi bahan pengetahuan masa silam yang tersembunyi. Candi Kalasan, Mendut, Prambanan, Sewu, Plaosan, Sukuh, merupakan bukti peradaban masa itu Budha dan Hindu serta berbagai aliran kepercayaan Jawa hidup saling berdampingan.

Masih banyak teka teki dan misteri yang belum terungkap bagaimana kehidupan dimasa silam, spiritualitas yang tinggi mampu menghadirkan seni yang indah, teknologi tinggi tentu didasarkan pada ilmu pengetahuan yang luas. Suatu karya besar seperti Borobudur ini tentu dibangun dengan pengorganisasian yang kuat dan dedikasi yang tinggi. Puncak peradaban Borobudur hingga kini masih dapat ditelusuri dari peninggalan candicandi yang masih tegak hingga kini.

\section{Pasang Surut Peradaban}

Berbagai teka-teki masih menyelimuti Borobudur, bagaimana prosentase pencapaian kejayaan peradaban tersebut dan seberapa luas wilayah pengaruh peradaban itu. Keruntuhan dinasti yang berkuasa juga masih menjadi misteri. Apakah ada konflik suksesi kepemimpinan yang gagal sehingga terjadi perebutan kekuasaan dan berkembang menjadi perang saudara? Ataukah karena bencana alam letusan Gunung Merapi atau gempa bumi dahsyat, sehingga menimbulkan bencana yang berkepanjang-an hingga Borobudur ditinggalkan.

Berabad-abad selanjutnya pusatpusat peradaban bergeser ke wilayah pesisir yang dianggap memiliki akses luas untuk menjelajahi dan menjajahi wilayah kekuasaan lain. Sriwijaya merupakan salah satu kerajaan yang penting dan kuat di pesisir Sumatra Timur menghadap Selat Malaka. Pengaruhnya hingga sekitar 
kawasan Asia Tenggara pada masanya merupakan peradaban yang kuat.

Kemudian tumbuh lagi kerajaan di intermountains basin seperti Singasari dan Majapahit. Kerajaan-kerajaan 'pedalaman' ini memiliki pasukan laut yang mampu melakukan ekspedisi ke berbagai kawasan untuk berdagang dan memperluas pengaruh, tidak jarang timbul konflik dan peperangan.

Selepas era Majapahit, muncul kerajaan Demak di pesisir Jawa utara. Hubungan kota-kota pesisir dengan bangsa luar seperti Cina dan Arab dilakukan melalui perdagangan. Kemudian muncul kekuatan di 'pedalaman' seperti kerajaan Pajang yang kemudian berkembang seperti pinang dibelah dua, dengan berdirinya Kasultanan Yogyakarta dan Kasunanan Surakarta.

Pasang surut peradaban tidak saja karena konflik dan runtuhnya moral dan sendi-sendi kehidupan masyarakat, tetapi juga berkaitan erat dengan pengaruh luar baik melalui peperangan ataupun perdagangan. Setelah pasang surut sistem kerajaan silih tumbuh hilang berganti, maka pada abad XVII tibalah suatu zaman dimana penguasaan dilakukan oleh bangsa asing dari benua Eropa. Bangsa Eropa yang semula melakukan perdagangan, berlanjut menancapkan kuku pengaruhnya di berbagai belahan dunia.

Bila kita refleksikan sejarah pengaruh kolonial terhadap peradaban masyarakat kepulauan Nusantara ini dapat dicermati beberapa pergeseran kekuasaan dari para penguasa kerajaan lokal ke pemerintahan kolonial. Kepentingan penguasa yang dominan lebih menentukan arah dan kebijakan penguasa lokal. Misalnya merosotnya industri perkapalan di Jawa, terkait dengan kebijakan kehutanan yang dikeluarkan oleh Gubernur Daendels yang melarang penebangan kayu jati di Pulau Jawa, sehingga harga kayu jati menjadi mahal (Soetrisno, 1994).

Penggunaan kayu jati untuk konstruksi rel kereta api yang dibangun akhir abad XIX, juga merupakan perubahan orientasi baru yang menghubungkan pesisir (Batavia) dan pusat-pusat permukiman dan produksi di pedalaman. Keadaan ini mengakibatkan kesulitan suplai kayu untuk industri kapal. Sementara itu terjadi pula perubahan teknologi perkapalan yang menggunakan bahan metal dengan teknologi baru.

At the end of the century, however, the traditional industry was moribund, and only Madura could still be regarded as a centre of indigenous ship-building. This had been caused by a combination of much stricter forest regulations, improved overland connections (railways!), competition by other sea-faring Indonesians (Bugis from Sulawesi), and the triumph of the iron steamship (Boomgard, 1991:30).

Maju mundurnya peradaban masyarakat dapat dipengaruhi dari kondisi internal dan perubahan lingkungan ekternal. Dari pendapat Boomgard di atas dapat ditarik pelajaran bahwa kebijakan penguasa terhadap sektor kehutanan dapat berpengaruh pada sektor lain. Misalnya, industri perkapalan, demikian pula dengan perkembangan teknologi transportasi kereta api dapat menjadi pesaing bagi industri perkapalan. Disini nampak bahwa perubahan teknologi termasuk transportasi telah mendorong kemajuan wilayah pedalaman.

Perkembangan ekonomi era kolonial pada masa lampau, dikenal adanya 
perkembangan sektor perkebunan yang menonjol dengan pengerahan tenaga kerja dan pengelolaan penguasaan lahan yang luas. Setelah Raffles, nama Van den Bosch yang memimpin pada dekade ketiga abad XIX menerapkan sistem perkebunan (a system of forced cultivation). Ia menerapkan tanaman indego di Priangan, Cirebon dan Tegal hingga siap dipasarkan ke Eropa pada akhir 1831. Kemudian berturut-turut dikembangkan komoditas perkebunan lainnya seperti tebu, kopi, kayu manis (cinnamon).

Perkembangan komoditas perkebunan, baik peningkatan produksi maupun permintaan dan harga pasar di Eropa yang tinggi, menjadikan sektor perkebunan menjadi 'generator ekonomi' yang menguntungkan bagi Belanda. Keuntungan ini sebagian diinvestasikan untuk membangun infrastruktur seperti jaringan rel kereta api dan jalan, jembatan, pelabuhan untuk mendukung pengembangan perkebunan. Dalam waktu singkat, Van den Bosch telah mengubah arah pengembangan pertanian dan pengerahan tenaga kerja menuju ke orientasi produk tanaman ekspor.

By the early 1840s, the cultivation system stood as a triumph of Dutch imperialism in the Indies. Within the little more than a decade, a few hundred Dutchman had changed the face of agricultural and labor practices in Java, dramatically raised the levels of export crop production, build roads, bridges, harbors and offices to accommodate the new system and most important of all as far as the Dutch were concerned, created a substantial and indispensible source of income for Holland's treasury (Elson, 1994:99).

Ironisnya, keuntungan dari sektor perkebunan yang dinikmati oleh Belanda tidak tercermin pada perbaikan taraf hidup buruh perkebunan yang bekerja keras di lapangan. Bahkan ketika Belanda menikmati kemakmuran, pada tahun 1840 di Jawa terjadi gelombang kelaparan yang disebutkan sebagai "the first wave of famines" (Elson, 1994). Pada tahun 1844 dilaporkan terjadi kegagalan panen padi di wilayah 'lumbung padi' Indramayu dan wilayah pesisir lainnya sebagi dataran penghasil padi di Cirebon, Karawang, Rembang, Surabaya, dan Jepara.

Kegagalan panen terjadi disebabkan musim kering yang panjang di satu sisi dan terbengkalainya pengelolaan irigasi dan pengolahan sawah disisi lainnya. Dilaporkan pula bahwa gelombang kelaparan kemudian diikuti dengan wabah epidemi typhoid fever antara tahun 18461850. Perombakan bidang pertanian kearah perkebunan dengan orientasi ekspor, ternyata telah melemahkan ketahanan pangan rakyat (padi sawah) termasuk juga kemerosotan sektor perikanan di Jawa. Keadaan ini memaksa Belanda untuk merevisi kebijakan kearah multi sektor dan alokasi tenaga kerja.

Berbagai upaya mobilisasi tenaga kerja dilakukan untuk bekerja di perkebunan di Jawa dan Sumatra, bahkan ada yang dibawa oleh Belanda untuk dipekerjakan di Suriname satu wilayah di benua Latin Amerika. Perubahan penyerapan tenaga kerja semacam ini dapat mempengaruhi pula sektor lainnya seperti menurunnya suplai tenaga kerja sektor perikanan. Akibatnya kegiatan industri perkapalan dan perikanan dapat merosot karena berbagai sebab terkait dengan kebijakan dan perubahan eksternal diatas maupun adanya 'entropi' dari dalam.

Ekspansi pengembangan lahan perkebunan ini yang kemudian menemukan Borobudur yang tertutup semak belukar 
dan hutan. Pada masa penjajahan Belanda, Sir Thomas Stamford Raffles, Gubernur Jenderal Britania Raya di Jawa, mendengar adanya penemuan benda purbakala di desa Borobudur. Raffles memerintahkan penyelidikan lokasi penemuan, berupa bukit yang dipenuhi semak belukar itu. Setelah lama dilakukan penelitian, baru pada tahun 1907, Theodoor van Erp mulai memimpin pemugaran hingga tahun 1911. Kemudian setelah lama terhenti, pada tahun1926, Borobudur dipugar kembali hingga terjadi Perang Dunia. Pada masa setelah kemerdekaan Republik Indonesia, beberapa kali upaya kajian dan pemugaran dilakukan.

Berdasarkan pada fakta perjalanan sejarah di atas, dapat diambil pelajaran bahwa dalam mengkaji perkembangan dan kemerosotan suatu peradaban, tidak cukup hanya dengan mempelajari karakter wilayah, tata ruang, sumber daya alam dan lingkungan, tetapi terkait dengan bagaimana manusia mengolah daya dan mewujudkan karya melalui dinamika sosial budaya masyarakat, kebijakan pemerintah, maupun kekuatan ekonomi yang tidak lepas dari perubahan lingkungan global.

Mengacu uraian historis tersebut memperlihatkan bahwa surutnya suatu peradaban bisa terkait dengan salah satu faktor atau kombinasi dari beberapa faktor penyabab utama yaitu: kerusakan lingkungan hidup, perubahan iklim dan bencana, diserang bangsa lain, konflik internal, tertutupnya akses hubungan (perdagangan) dengan bangsa lain (Diamond, 2005). Teka teki keruntuhan Borobudur bisa jadi terkait dengan faktor lingkungan dan bencana, tetapi bisa jadi terkait adanya konflik perebutan kekuasaan.

Pada tahun 2006 lalu diselenggarakan peringatan 1.000 tahun letusan besar Gunung Merapi diadakan sarasehan dan fieldtrip di sekitar Borobudur dan Prambanan. Kegiatan ini menjelajahi berbagai kemungkinan mengenai letusan Merapi, tetapi masih teka-teki (Zen, 2006). Diperkirakan letusan terjadi pada tahun 1006 dan akibatnya terhadap keruntuhan kerajaan Mataram Hindu. Setelah saresehan banyak teka-teki belum bisa dijawab dan ini merupakan tantangan untuk melakukan studi lebih mendalam dan sekaligus lebih meluas (terpadu).

Kemampuan suatu bangsa menghadapi krisis memang sangat tergantung bagaimana respon bangsa tersebut terhadap apa yang dihadapinya. Krisis dapat mengakibatkan melemahnya struktur kekuasaan dan bisa menimbulkan suksesi kepemimpinan yang dipenuhi dengan konflik, namun demikian krisis bisa merupakan ujian bagi menguatnya solidaritas dan meningkatkan kelas serta kualitas kehidupan sehingga menjadi bangsa yang unggul. Sekelumit refleksi perjalanan sejarah di atas, dapat menjadi bahan untuk melihat masa depan.

\section{Penemuan Kembali dan Pemugaran Borobudur}

Berbagai sumber penelitian antara lain Winarni, 2006 dan Soeroso, 2007 dapat ditelusuri mengenai penemuan kembali dan pemugaran Borobudur. Candi Borobudur ditemukan kembali pada tahun 1814 oleh para pemerhati kepurbakalaan bangsa Belanda. Sebenarnya bangsa asing ini menemukan dalam arti mengupas kawasan ini dari selimut hutan dan semak belukar yang menutupi bangunan candi. Berbagai upaya untuk mengungkapkan lebih jauh tentang candi ini banyak dilakukan, antara lain melalui pembersihan, penelitian, pendokumentasian, serta perbaikan yang terutama dilakukan. 
Selain menjadi bahan kajian ilmiah, candi ini sejak awal juga telah menjadi tempat wisata bagi sementara pejabat pemerintah kolonial. Keinginan untuk menyelamatkan dan melihat Candi Borobudur megah kembali diwujudkan dengan pemugaran teras-teras atas candi ini oleh pemerintah Belanda di bawah pimpinan Theodoor van Erp pada tahun 1907 - 1911. Pemugaran pertama ini masih bersifat parsial dan belum mampu menahan berbagai kerusakan fisik yang terjadi di bagian-bagian lain.

Sesudah kemerdekaan Negara Republik Indonesia, upaya untuk menyelamatkan candi Borobudur dari kehancuran terus dilakukan oleh pemerintah. Sejak tahun 1955, Pemerintah Indonesia mulai mencoba menggalang bantuan internasional melalui UNESCO untuk membantu penyelamatan dan pemugaran Candi Borobudur. Akhirnya, mulai tahun 1973 candi Budha terbesar di dunia ini mulai dipugar yang secara lebih cermat dan sistematis dengan teknologi maju yang melibatkan berbagai keahlian dan ahli-ahli dari beberapa negara.

Bersamaan dengan proses pemugaran yang sedang berlangsung, pada tahun 1973 -1979, pemerintah Indonesia melakukan kajian teknis dan studi kelayakan untuk membuat Taman Purbakala Nasional Borobudur. Sebagai hasil kajian-kajian tersebut, tim peneliti mengajukan konsep 3 pilar pengembangan Borobudur ke depan. Konsep inilah yang dikembangkan sebagai tujuan utama dan ciri pengarah pemugaran Candi Borobudur, yaitu: (1) Taman untuk perlindungan abadi bangunan candi; (2) Borobudur sebagai pusat penelitian arkeologi Indonesia; (3) Pelestarian untuk anak-anak masa depan (generasi mendatang).
Selama restorasi telah dilakukan pemintakatan (zonasi) dan deliniasi masing-masing zona dalam rangka pengelolaan dalam 5 zona, yaitu

- Zona I adalah zona inti berupa bangunan candi atau sanctuary area (radius $200 \mathrm{~m}$ dari pusat candi, meliputi area seluas $44,8 \mathrm{ha}$ )

- Zona II adalah zona penyangga (buffer zone) taman arkeologi dengan fasilitas untuk pengunjung, perkantoran, parkir, ruang pameran (radius $500 \mathrm{~m}$, luas $42,3 \mathrm{ha}$ )

- Zona III adalah untuk mendukung pengendalian perlindungan tata letak candi (radius $2 \mathrm{~km}$, luas $932 \mathrm{ha}$ )

- Zona IV adalah zona pelestarian kawasan sejarah (radius $5 \mathrm{~km}$ ) yang di dalamnya terdapat 13 situs arkeologi.

- Zona $\mathrm{V}$ adalah perlindungan kawasan sejarah, dengan 21 situs arkeologi.

Tahun 1980, dalam rangka persiapan pengelolaan Taman Purbakala, didirikan PT. Taman Wisata Candi Borobudur (TWCB) dan Prambanan sebagai lembaga yang dipersiapkan untuk mengelola taman tersebut. Dengan pendirian PT TWCB tersebut ternyata juga telah merubah tujuan pendirian taman, dimana tujuan awal adalah Taman Purbakala Nasional kemudian menjadi Taman Wisata. Tahun 1983, proses pemugaran Candi Borobudur dinyatakan selesai dan dibuka untuk umum dengan upacara peresmian oleh Presiden RI Soeharto. Baru pada bulan tahun 1991, untuk melakukan pelestarian terhadap Candi Borobudur secara terus menerus didirikan Balai Studi dan Konservasi Borobudur dengan Surat Keputusan Menteri Pendidikan dan Kebudayaan Nomor 0605/O/1991 tanggal 30 November 1991. 


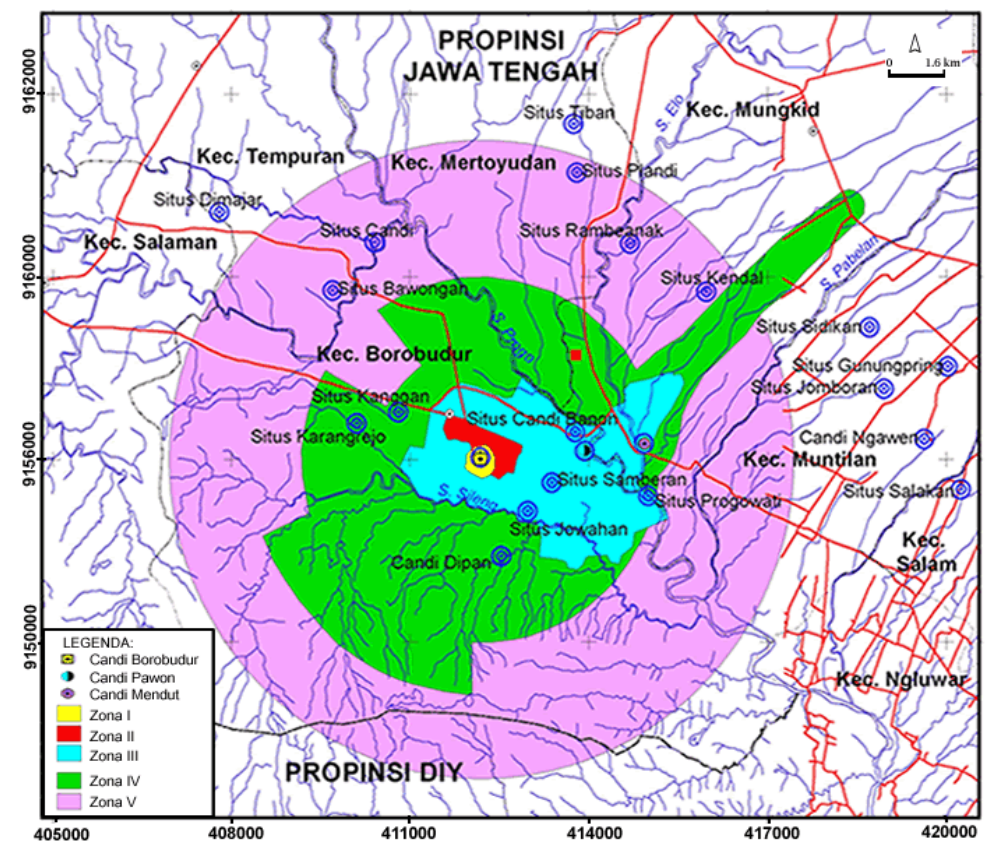

Sumber: - Peta Rupa Bumi Indonesia (RBI) Skala 1: 25.000 Tahun 2001 - Peta Zonasi Pengelolaan Borobudur dari JICA

Gambar 1. Peta Zonasi Pengelolaan Borobudur

\section{Borobudur sebagai Magnet Pariwisata}

Borobudur dapat dilihat dalam berbagai sudut pandang dengan segala dimensinya. Bagaimana Borobudur dilihat dari perspektif pariwisata, sangat tergantung siapa dan atas kepentingan apa Borobudur diletakkan. Memandang Borobudur sebagai daya tarik atau magnet pariwisata merupakan salah satu aspek untuk memanfaatkan sekaligus mengkonservasi situs warisan budaya.

Borobudur kini ibaratnya sebuah buku kehidupan yang mengandung banyak pelajaran. Pengembangan pariwisata Borobudur dalam pandangan penulis, perlu alternatif yaitu berbasis pengetahuan dan pengalaman guna menemukan nilai-nilai penghidupan (livelibood/economy), kehidupan (social), kemanusiaan (buman/Well-being), kesemestaan alam (nature) dan ketuhanan.
Konsep Compass of Sustainability dikenal adanya Empat Penjuru Mata Angin dalam merumuskan konsep dan arah pembangunan berkelanjutan (AtKisson Groupe International, 2006). Arah utara (North) dikaitkan dengan dimensi alam (Nature). Arah timur (East) dikaitkan dengan pentingnya ekonomi dikembangkan. Arah selatan (South) berkaitan dengan pengembangan sosial demikian pula arah barat (West) dikaitkan dengan pentingnya membangun kehidupan manusia dalam kesejahteraan dan seseimbangan spiritualitas (Well-being). Dalam kehidupan masyarakat Jawa dikenal Kiblat Papat Limo Pancer, sebagai pengarah kehidupan manusi. Pariwisata sebagai lokomotif pembangunan, memerlukan kompas untuk menuju arah yang berkelanjutan. Konsep ini sesungguhnya sederhana saja, setiap orang perlu memahami kemana arah yang dituju, mana jalan yang dipilih, kendaraan (organisasi) apa yang ingin digunakan. 


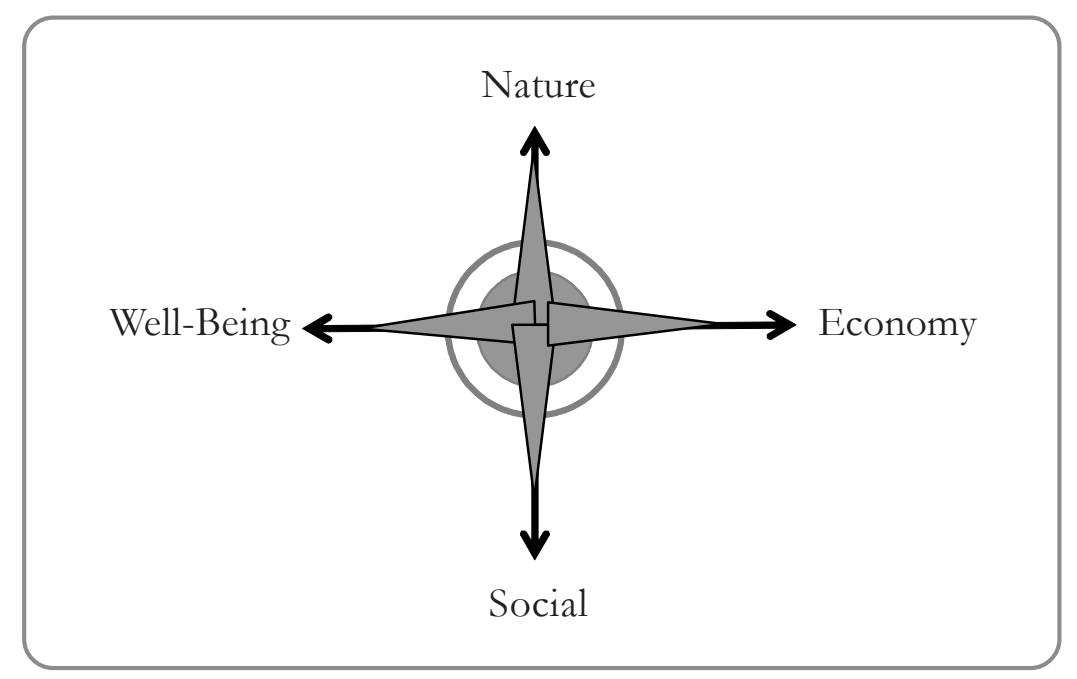

Sumber: AtKisson Groupe International, 2006

Gambar 2. Compass of Sustainability

Pariwisata tidak hanya perjalanan fisik dari satu tempat ke tempat lain yang berbeda budayanya, tetapi juga bisa dikemas menjadi perjalanan imajinasi melintas batas waktu masa lalu dan masa depan. Dengan melihat dan menikmati warisan sejarah seperti halnya Borobudur, wisatawan dapat berkelana dalam perjalanan imajinasi peradaban masa silam dan merangkai dengan masa kini serta membayangkan masa depan peradaban manusia. Pariwisata seperti ini yang meramu kemampuan berbagai pengetahuan dan bukti penemuan yang diinterpretasi dan dijadikan rangkaian cerita yang menarik. Pariwisata holistik berbasis pengetahuan dan dikemas dengan pendidikan ini nampaknya memiliki prospek yang bagus, dibanding pariwisata yang mengandalkan jumlah kunjungan dan pendapatan semata.

Borobudur sebagai magnet, memiliki gaya atau kekuatan sentripetal dan sentrifugal yang harus digerakkan secara sinergis, dinamis dan harmonis. Bila dua kekuatan pengembangan Borobudur ini digerakkan, maka kekuatan magnet yang muncul semakin kuat hingga mampu memancarkan energi gerak elektromagnetik yang bisa ditransformasi menjadi cahaya. Penjelasan kedua gaya kekuatan ini lebih dimaknai dari sudut pandang pengembangan masyarakat dan pembangunan wilayah Borobudur dikaitkan dengan pariwisata.

\section{a. Kekuatan Sentripetal}

Sentripetal merupakan gaya yang bergerak dari luar menuju ke dalam. Borobudur menjadi magnet yang sangat kuat, tidak saja karena pengakuan sebagai salah satu World Heritage oleh UNESCO, tetapi memang memiliki keunikan daya tarik dan daya pikat tersendiri. Wisatawan yang berkunjung ke Yogyakarta dan Jawa Tengah, merasa belum lengkap bila belum berkunjung ke Borobudur.

Letaknya yang berada di pusatnya Pulau Jawa mudah terjangkau menggunakan jalan darat bagi wisatawan domestik, terutama pelajar dan kaum muda di berbagai kota di Jawa. Bagi wisatawan yang menggunakan pesawat udara lebih mudah melalui Yogyakarta, Semarang dan 
Solo dan melanjutkan dengan kendaraan menuju Borobudur.

Kekuatan sentripetal sebagai kekuatan yang menarik dari luar ke dalam, menyebabkan Borobudur menjadi magnet yang menarik bagi investasi pariwisata dan mobilitas tenaga kerja menuju kawasan ini. Sehingga saat ini beban yang diemban tata ruang kawasan Borobudur semakin berat dan cenderung menjadi ruwet di masa depan. Kehadiran berbagai investasi skala besar dalam penggunaan ruang dan sumber daya di kawasan ini telah menunjukkan gejala yang mengkhawatirkan.

Pembangunan yang terus meningkat membawa konsekuensi bagi kehidupan, tata ruang dan lingkungan hidup. Beban yang terlalu besar sebagai magnet pariwisata, telah membawa perubahan citra Borobudur warisan dunia ini semakin merosot. Belum lagi meningkatnya pengalihan kepemilikan lahan dari petani dan penduduk setempat pada para spekulan tanah. Bila kecenderungan ini terus berlangsung dikhawatirkan terjadi marjinalisasi, penduduk setempat terpelanting dari tanah leluhurnya.

\section{b. Kekuatan Sentrifugal}

Sentrifugal merupakan gaya melanting dari dalam ke luar. Kekuatan ini bisa jadi merupakan reaksi setelah terjadi kejenuhan dari dalam, tapi juga bisa dikendalikan sebagai upaya mengurangi kejenuhan dan beban yang ditimpakan pada Borobudur. Kecenderungan yang pertama merupakan reaksi atas beban yang terus menerus menekan Borobudur, sehingga terjadi reaksi balik daya dorong sentrifugal. Kecenderungan kedua merupakan upaya sebelum terjadi kerusakan yang hebat akibat beban yang menumpuk di sekitar Borobudur, dilakukan pemekaran atau perluasan atau bahkan orientasi yang menarik di luar Borobudur.

Pengembangan wisata diarahkan pada landscape yang lebih luas, diluar kawasan inti Borobuudur. Dengan melihat dan menggarap kawasan wisata baru di desa-desa sekitarnya, di lereng pegunungan dan di puncak-puncak perbukitan akan memberikan alternatif yang baru. Borobudur akan menjadi menarik bila dipandang dari berbagai sisi dikejauhan. Justru dari pandangan yang jauh sesungguhnya dapat muncul keindahan dan imajinasi yang luar biasa.

Pengembangan kawasan wisata secara sentrifugal diperlukan untuk mengurangi beban yang diemban kawasan inti Borobudur, sekaligus untuk menebarkan pemerataan pembangunan desa-desa di sekitarnya. Peran pemerintah daerah sangat penting di era otonomi, demikian pula dalam pembangunan pariwisata mau tidak mau harus dengan daerah.

\section{Pariwisata Sebagai Lokomotif Pengembangan Wilayah}

Sifat pariwisata yang dinamis terus mengalir dan mudah terjadi fluktuasi, memerlukan pemahaman yang terbuka dan pengelolaan yang fleksibel. Pengembangan pariwisata memerlukan sinergi antar pelaku dan pemangku warisan Borobudur. Pada era otonomi ini, perlu diperhitungkan peran pemerintah daerah dan partisipai masyarakat dalam menentukan arah pembangunan. Kerjasama antar daerah di lembah antar pegunungan di sekitar Borobudur perlu dikembangkan seperti Magelang, Sleman, Yogyakarta, Kulonprogo, Purworejo, Klaten, Solo, Boyolali, Salatiga, Semarang, Temanggung, Wonosobo. 
Wilayah Joglosemar (Jogja, Solo dan Semarang) dan sekitarnya ini memiliki serangkaian warisan peradaban yang dapat dirangkai menjadi kekuatan bagi pengembangan tema dan trip wisata yang menarik. Tidak jauh dari kota Yogyakarta banyak candi yang unik, sebelah utara Solo terdapat situs purbakala Sangiran dan kearah Wonosobo di dataran tinggi Dieng terdapat candi-candi diketinggian yang memiliki posisi sejarah unik pada masanya. Jalur wisata Borobudur dapat ditarik secara sentrifugal ke berbagai arah menuju berbagai alternatif tema dan trip seperti terlihat pada peta berikut ini.

Sinergi program pembangunan baik yang berbasis sektor maupun tata ruang dan kependudukan perlu dilakukan dalam keterkaitan dengan Borobudur. Sinergi merupakan upaya yang dimulai dari komitmen, koordinasi, keterkaitan, kerjasama dan kemitraan hingga menghasilkan manfaat yang dapat dirasakan bersama. Kebersamaan ini tentu tidak mudah ditengah arus kompetisi atau persaingan antar daerah dalam menggaet investor dan wisatawan. Beberapa bibit sinergi ini tengah bersemi, misalnya Java Promo merupakan wadah kerjasama lima belas kabupaten dan kota lintas propinsi di Yogyakarta, Jawa Tengah. Inovasi institusi ini pantas mendapat dukungan untuk terus bisa membuahkan hasil yang nyata dan bermanfaat bagi segenap pelaku dan masyarakat pada umumnya.

Keterkaitan pengembangan pariwisata dan konservasi Borobudur, seyogyanya dilakukan tidak hanya di kawasan zona inti, tetapi perlu dikembangkan pembangunan terpadu secara lebih luas dilakukan di binterland. Harmoni pengembangan wilayah ini merupakan upaya untuk mengurangi beban di zona inti Borobudur, sekaligus melakukan pemerataan pembangunan di pedesaan. Jadi Borobudur tidak hanya sebagai magnet pariwisata dengan gaya sentripetal, tetapi dengan mengembangkan gaya sentrifugal Borobudur dapat menjadi generator pembangunan harmoni dan terpadu (holistik).

Pariwisata berbasis masyarakat merupakan pendekatan dan praksis pariwisata yang menempatkan masyarakat sebagai pelaku utama. Masyarakat tidak hanya sebagai pelayan bagi wisatawan, tetapi sebagai pemangku budaya dan tradisi serta sebagai tuan rumah yang memiliki kedaulatan. Pariwisata ini dapat tumbuh pada masyarakat yang masih memiliki semangat gotong-royong, namun tidak dapat dilakukan pada masyarakat yang individualistik.

Masyarakat setempat yang pada umumnya memiliki nilai-nilai budaya tradisional pedesaan menganggap candi Borobudur tetap menjadi bagian dari budaya mereka. Hal ini dinyatakan oleh kerinduan mereka untuk selalu dapat melaksanakan tradisi atau kegiatan seperti yang dulu pernah mereka lakukan di saatsaat tertentu. "Ikatan batin" ini merupakan rasa handarbeni ada rasa memiliki dan melestarikan. Namun kebijakan yang menempatkan Borobudur (secara dominan) sebagai arena wisata telah menimbulkan rasa kekecewaan yang besar ketika candi Borobudur dipisahkan dari kehidupan budaya mereka. Kekecewaan ini seringkali mendorong mereka untuk cenderung menuntut "kompensasi" tertentu kepada pihak-pihak yang kini mengelola candi ini

Pengelolaan Borobudur saat ini lebih berorientasi ekonomi melalui kegiatan pariwisata yang bersifat masal. Berbagai kegiatan masyarakat lokal tidak mudah dilaksanakan di lingkungan candi, kecuali dengan ijin atau membayar tiket. Berbagai 
upaya dialog, sarasehan dan diskusi telah dilakukan, tidak lain untuk untuk 'membuka pintu' bagi kegiatan sosial budaya Borobudur.

Kegiatan seni budaya masyarakat kini tumbuh di berbagai desa di lereng pegunungan. Para pegiat seni dan budaya beberapa tahun terakhir menunjukkan geliat kebangkitan masyarakat. Peran warung informasi Jagat Cleguk dan komunitas sanggar lainnya bahu membahu menyelenggarakan festival seni budaya desa. Secara gotong royong berbagai pagelaran diselenggarakan dengan semangat gegap gempita. Semangat dan dinamika masyarakat ini layak mendapat perhatian dan dukungan dari pemerintah, mengingat ini merupakan suatu kebangkitan gaya sentrifugal yang dapat memperbesar daya tampung wisatawan tidak hanya di sekitar zona inti Borobudur, tapi bersemi di desadesa sekitarnya yang menawarkan wisata alternatif.

Wisata tematik dan alternatif yang berorientasi kedaulatan sosial budaya masyarakat tentu lebih menarik daripada wisata konvensional yang berorientasi ekonomi. Kesenderungan ini harus digali dan dikembangkan serta dipromosikan, sehingga masyarakat mendapat manfaat dan mampu menyuguhkan yang terbaik bagi tamunya, wisatawan.

Borobudur dipandang secara holistik, dari segi pariwisata dirumuskan konsep sustainable tourism (termasuk didalamnya berbagai istilah percabangan dan keragaman nama/lebel pariwisata seperti community based tourism, ecotourism, cultural tourism, geoscientific based tourism) sebagai upaya pemanfaatan dan pelestarian. Sebelum pemerintah ingin mengundang investor besar dan dari luar, masyarakat harus dilibatkan tidak sekedar sosialisasi atau jaring aspirasi, juga terlibat dalam proses implementasi dan pengendalian. Berkaitan dengan pendanaan, pemerintah harus menggali sumber-sumber dana dari dalam maupun luar negeri yang tidak berupa hutang.

\section{KESIMPULAN DAN SARAN}

Kesimpulan penelitian ini terkait dengan fenomena keberadaan Borobudur beserta teka-teki sejarah masa lalu maupun sebagai magnet pariwisata saat ini, sebagai berikut:

1. Peradaban Borobudur pernah mengalami masa kejayaan, namun masih menjadi teka-teki untuk menjelaskan mengapa terjadi kemunnduran dan bahkan keruntuhan serta ditinggalkan. Berbagai hal yang dapat menjadi penyebabnya, kemungkinan besar adalah adanya bencana alam erupsi vulkanik Gunung Merapi.

2. Kaitannya dengan pemanfaatan Borobudur sebagai magnet atau daya tarik pariwisata menunjukan pamor atau citranya semakin memudar. Hal ini tidak lepas dari pemanfaatan yang semakin meningkat tetapi tidak diikuti dengan upaya perbaikan pengelolaan dan pengembangan inovasi produk.

3. Permasalahan yang menyelimuti Borobudur terkait dengan jumlah wisatawan dan perilaku yang merusak ketika ribuan orang naik ke atas candi dan memegang berbagai relief serta patung yang dapat menimbulkan kerusakan batu serta wujud dan sudut ukiran relief.

4. Permasalahan kenyamanan wisatawan terganggu akibat perilaku para 
pengasong dan pedagang souvenir yang jumlahnya banyak, mengerubungi dan menyodorkan barang dagangan untuk dibeli.

5. Ancaman kerusakan akibat menurunnya kualitas lingkungan, kemungkinan hujan yang mengandung zat yang merusak relief dan patung batu serta bentuk candi. Meningkatnya polusi udara maupun perubahan cuaca global dikhawatirkan akan merusak Borobudur di masa depan.

Hasil penelitian ini mengajukan beberapa saran yang ditujukan bagi segenap pihak dengan arahan sebagai berikut:

1. Perlunya adanya kajian lebih lanjut dari berbagai disiplin ilmu mengenai pentingnya konsep dan strategi pelestarian, pemanfaatan maupun pengelolaan Borobudur dan mempublikasikan pandangannya maupun penemuannya mengenai fenomena kehidupan masa lalu yang dapat menjadi pelajaran berharga bagi generasi mendatang.

2. Borobudur tidak hanya sebagai magnet atau daya tarik wisata yang mengandalkan jumlah wisatawan, tetapi lebih baik mengelola dan mengembangkan kegiatan wisata yang berkualitas sebagai proses pembelajaran dan pengkayaan pengetahuan bagi para wisatawan. Para pelaku bisnis pariwisata perlu melakukan inovasi paket-paket wisata dengan mengintegrasikan pengetahuan dan pembelajaran dalam penjelajahan peradaban.

3. Pengembangan pariwisata berbasis masyarakat penting untuk menjalin keterkaitan antara Borobudur dengan budaya sekitarnya. Masyarakat sesungguhnya sebagai pengemban budaya dan oleh karena itu pengembangan pariwisata harus melibatkan masyarakat setempat.

4. Pengelolaan tidak hanya ditekankan pada zona inti Candi Borobudur dan penyangga dalam, tetapi perlu dikembangkan konsep Gaya Sentrifugal dengan mengembangkan binterland disekitarnya menjadi bagian dari pengembangan keragaman atraksi dan amenitas pariwisata.

5. Pemerintah pusat hendaknya dapat meninjau kembali kebijakan pengelolaan yang telah lama berjalan, untuk dapat dikembangkan suatu pendekatan dan konsep maupun strategi pengelolaan yang melibatkan berbagai pihak dengan sifat yang transparan, tegas dan konsisten.

\section{UCAPAN TERIMA KASIH}

Penulis mengucapkan terima kasih pada tim peneliti yaitu Winarni dari Departemen Kebudayaan dan Pariwisata, Daud Tanudjoyo (Arkeolog), Heidi Shri Ahimsa (Antropolog), Laretna T. Adishakti (Arsitek), Amiluhur Soeroso (Ekonom) dan Helmi Marwoto (Geolog) atas kerjasama penelitian dan pengkayaan bahan mengenai Borobudur. Tulisan ini pernah diseminarkan dalam "Re-Thinking Borobudur: Penataan Ruang Kawasan the World Cultural Heritage Candi Borobudur" yang diselenggarakan Departemen Pekerjaan Umum dan Departemen Kebudayaan dan Pariwisata di Jakarta pada 2008. Berbagai masukan diskusi kemudian dikembangkan untuk memperbaiki tulisan ini. 


\section{DAFTAR PUSTAKA}

Anonim. 2007. The Thousand Mysteries of Borobudur. Visual Art Exhibition, 20 April - 9 May in Jogja Gallery.

AtKisson Group Internasional. 2006. The Business of Sustainability: Participant Workbook. LEAD and AGI. Jakarta

Boomgaard, P. 1991. "The Non-Agricultural Side of An Agricultural Economy Java 15001900" (Chapter I) dalam Paul Alexander, Peter Boomgaard, Ben White (editors). 1991. In The Shadow of Agriculture: Non-Farm Activities in the Javanese Economy, Past and Present. Royal Tropical Institute, Amsterdam.

Diamond, J. 2005. Collapse: How Societies Choose to fail or Survive. Penguin Group.

Elson, R.E. 1994. Village Java Under the Cultivation System 1830-1870. Allen and Unwin. Sidney.

Fagan, Brian. 2008. The Great Warming: Climate change and the rise and fall of civilization. Bloomsbury Press. New York.

Matroji. 2004. Sejarah untuk SMP Kelas VII. Penerbit Erlangga. Jakarta.

Siagian, R. 2002 . Indonesia Art \& Cultural Heritage. Yayasan Cempaka Kencana. Bandung dan Yogyakarta.

Soekmono. 1976. Chandi Borobudur: A monument of mankind. The UNESCO Press. Paris.

Soeroso, Amiluhur. 2007. Desertasi UGM : Penilaian Kawasan Pusaka Borobudur Dalam Kerangka Perspektif Multi Atribut Ekonomi Lingkungan dan Implikasinya Terbadap Kebijakan Manajemen Ekowisata.

Soetrisno, L. 1994. Masalah Sosial Budaya di Indonesia Menjelang Indonesia Memasuki Masyarakat Baru. Makalah Seminar HIPIIS Yogyakarta (tidak dipublikasikan).

Subaktini, Dewi. 2006. Analisis Sosial Ekonomi Masyarakat di Zona Rehabilitasi Taman Nasional Meru Betiri, Jember, Jawa Timur (Kasus di desa Andangrejo, Wonoasri, Curahnongko, dan Senenrejo), Forum Geografi Vol. 20 No. 1 Juli 2006.

Winarni. 2006. Kajian Perubahan Ruang Kawasan World Heritage Candi Borobudur, Program Studi Magister Perencanaan Kota dan Daerah, Jurusan Ilmu-ilmu Teknik, Universitas Gajah Mada.

Zen, MT. 2006. “Enigma Merapi dan Sejarah Mataram”. Makalah Saresehan Budaya V ulcano International Gathering 2006. UPN Veteran Yogyakarta 23 Februari 2006. 